\title{
NOLLYWOOD INTERVENTIONS IN NIGER DELTA \\ OIL CONFLICTS: A STUDY OF JETA \\ AMATA'S BLACK NOVEMBER
}

\author{
Emmanuel Onyekachukwu Ebekue* \\ \& \\ Michael Chidubem Nwoye* \\ http://dx.doi.org/10.4314/og.v15i1.6
}

\begin{abstract}
The discovery of oil in Oloibiri town in the Niger Delta region of southern Nigeria in 1956 has brought with it myriads of problems to the region. There has been lingering crisis in the region which has led to repeated loss of lives and properties. There have been countless efforts at finding a permanent solution to the conflict. However, there seems to be a renewed agitation and restiveness resulting from the stoppage of the amnesty program that was instituted by the late President YarAdua's federal government. It is against this background that the researcher embarked on this work in order to critically x-ray Nollywood's contribution to the peace effort with a special attention to JetaAmata's Black November (2012). The researcher used the case study approach of the qualitative research method in analyzing his data. Findings from the research showed that any solution to the lingering crisis aimed at long term must adopt a populist approach.
\end{abstract}

\section{Key Words: Nollywood, Niger Delta, Oil, Conflict, Intervention}

\subsection{Introduction}

The importance of film in human society has been underscored by critics. However, the potential of the film medium are yet to be fully utilized for national uplift and human development. Many countries of the world with the United States of America (USA) and India at the vanguard have used the film medium to give their people a better life. The film medium has continued to broaden its spectrum and is breaking bounds in new areas like conflict management, social development, psycho-therapy etc. According to Hopkinson (197), film as a medium of entertainment, is now more than a century old. 
Ebekue: Nollywood Interventions in Niger Delta...

However, he posits that, only recently has its great potential as an instructional and motivational tool been realized.

Film and theatre as works of art have potential of championing human development and therefore, cannot be relegated to the background. According to Nigerian Film Corporation Act, The role of the film industry as a tool for national mobilization towards nation building is enormous. It serves as a means of communicating, informing, enlightening, educating the populace. It also serves as a vehicle for projecting the richness of the nation's art and culture as well as natural endowments to the outside world. (1)

Nollywood, the nomenclature for the film industry of Nigeria, has, in the last two decades, been enjoying a massive local viewership. Nigeria has a keen, if relatively new, obsession with home-grown films almost exclusively shot on digital and available only on video. Thus without doubts, locally produced films have come to occupy an important place in the realm of Nigeria's contemporary communication culture which arguably positions them as a viable tool for ideological propagation and social change. They have become a platform for projection of communal experience, values and norms. Patrick Ebewo (46) argues that the film industry in Nigeria, now popularly referred to as Nollywood, which received impetus in 1993 with the release of the blockbuster Living in Bondage as produced by Kenneth Nnebue, has quickly and continuously gathered momentum over the last two decades emerging today as a force to reckon with globally.

Recently, the Niger Delta region has been receiving attention from Nollywood film producers. Some of these films such as Blood and Oil (2010), Oloibiri (2015) have been used to address the socioeconomic and political challenges confronting the region. It is an obvious fact that for over two decades, the Niger Delta has been engulfed by agitations on resource control which is connected to the rich deposit of oil within the region. A historical overview of violent conflicts within Niger Delta communities includes: Umuechem 1990; Obagi 1993, 1994; Odi 1999; Kula and Opukiri 1992, Eleme, Ogu and Okrika 1999, Ijaw and Itsekiri 1997-2003; Ogoni and Andoni 1993, 
1994; Ke and Bille 2001; Itsekiri and OkereUrhobo 1999; Bassambiri and Ogbolomabiri2005; Afiesere 2006; Okerenkoko, 2006, Gbaramatu Kingdom 2009, Ayakoromo 2010. With these conflicts, Niger Delta region may be referred to as a conflict zone.

However, several attempts and strategies such as Amnesty Programme of the President Yar'Adua administration has been made to mitigate the conflicts, but all were futile. Hence, films become intractable to conflict management and intervention. This has necessitated a paradigm shift in engaging the Nollywood as platform for managing conflicts using film narratives. Comparatively from a broader African spectrum the incidents of the 1994 Rwanda Genocide and Liberian Civil War between 1989 and 1997 have also been projected in films such as Sometimes in April (2005), Hotel Rwanda (2004), and Beasts of No Nation (2015). They mirrored conflicts, and then raised questions about the conflicts with the aim of finding lasting solutions to the conflicts. These films project the above conflicts in relation to their enormity directly, appeal and make recommendations for peaceful resolution. Hence, they open door for peace dialogues. It is against this backdrop that this study seeks to explore the Nollywood film titled Black November (2012) and its implications on the management of resource based conflicts within the Niger Delta Context. One case study has been chosen. The researcher used the case study approach of the qualitative research method for his data acquisition and analysis.

\subsection{An Overview of the Niger Delta Oil Region of Nigeria}

Niger Delta region of Nigeria, also known as South-South geopolitical zone of Nigeria, is "the delta of the Niger River sitting directly on the Bight of Biafra side of the Gulf of Guinea on the Atlantic Ocean in Nigeria" (Michael and McGinley,1). Onyeneje, Justina Chioma opine that, it covers an area of over 80,000 square kilometer, and consists of a number of distinct ecological zones which are characteristic of a large River Delta in a tropical region; costal ridge barriers, mangroves, freshwater swamp forests and lowland rain forests.

The region is crisscrossed by a web of creeks that link these rivers; Forecados, Num, Benin, Brass, Bonny (all estuaries of the River Niger), the Kwa-Ibo, the cross and other separate streams. Niger Delta is a very densely populated region; made up of 9 states which 
Ebekue: Nollywood Interventions in Niger Delta...

consist of 33 million people, with over 40 ethnic groups in 3,000 communities located between Longitudes $4^{\circ} 18^{\prime \prime}$ and $9^{\circ} 24^{\prime \prime} \mathrm{E}$ of the Greenwich Meridian and Latitudes $4^{\circ} 12^{\prime \prime}$ and $7^{\circ} 48^{\prime \prime} \mathrm{N}$ of the Equator. Some of the Ethnic groups include: Ogoni, Tai, Ikwerre, Ndoni, Egbema, Ogba and Ekpeye, Engenni, Degema, AbuaOdual and Obolo/Andoni in Rivers State. The Ibibios, Annang, Oron and Ibeno of Akwa-Ibom; the Ijaws, Urhobo, Itsekiri, Ikas and Ukwuani of Delta State; Other ethnic groups are Ilaje and Ikale in Ondo State; Igbos of Imo and Abia States and Egor, Oredo and Orhionwon of Edo State; Ejegham, Bekwara, Efiks, Agbo, Bahomono, Yakurr, Biasse, Etung, and Mbembe of Cross River State (NDDC 53).

Between the fifteenth and nineteenth centuries, the Niger Delta was a gateway into some of the markets in the West Africa interior. The introduction of the slave trade and the eventual change to palm oil trade brought this strategic location factor of the Niger Delta to the fore. Hence Onwubiko (102) affirms that this region was the great centre of trade with Europe; the slave trade from the 16th century to the early decades of the 19th century and then palm oil trade from the 19th century onwards. Consequently, one of the results of the slave trade in the Niger Delta was the emergence of city-towns along the coast, which was the outcome of the emigration of people from hinterland villages to the Delta fishing villages to take due advantage of the trade with Europeans. More so, city-towns like Warri and Sapele inhabited by the Itsekiri and Urhobo, Brass, Akassa, Town and Nenbe inhabited by the Efiks arose. In the 19th century these citytowns of the Niger Delta saw remarkable political and economic changes.

Niger Delta, however, is described as the oil-producing communities of the Southern region of Nigeria as oil exploration from the region is the beam of the country's economy. Hence, it generates billions of dollars for the government since oil was first discovered in 1956. Despite this huge amount of money, the local people in the Niger Delta live in abject poverty that expresses a state of deprivation, to the extent that the people have no access to basic social amenities, like good water and electricity (Oviasuyi and Uwadea, 115). The majority of the Niger Delta people live in creeks, where they watch daily seeing the oil industries making a fortune from the petroleum deposits in the region. Similarly, Ejibunu (10) opines that the region tends to be a place "where time seems to have stood still and where 
people live in poverty, leaving the residents of the region without any other option than to be bitter and angry over the neglect of the people by the federal government.

Ejibunu reflected on the comment made by Mukagbo, the $\mathrm{CNN}$ reporter on Inside Africa. According to him: "In Niger Delta, a scene of abject poverty pervades the area, which is very similar to what one is likely to find in a refugee camp notwithstanding the fact that the region fetches the government the money for running the affairs of the state" (10). Consequently, poverty and deprivation in the region has been the two major factors behind agitations of the people of the Niger Delta region over the years. Corroborating the above view, Oviasuyi and Uwadea (115) argue that prior to when oil was discovered in the Niger Delta area, agriculture was the mainstay of the people and the major source of revenue for both state and federal government.

\subsection{Genesis of the Niger Delta Oil Conflict}

The Niger Delta region of Nigeria is regarded as one of the richest deltas in the world; ranked alongside other major deltas with crude oil and natural gas in the Amazon in Brazil, Orionoco in Venezuela, Mahakam in Indonesia and Mississippi in the United States of America (Petters: 197). The natural physical characteristic of the Niger Delta topography poses enormous geographical challenges and obstacle towards its development. The Niger Delta region is widely known for its rich oil and gas reserves which contribute enormously to the economic prosperity of the Nigerian nation. The region has some unique characteristics which tend to make development difficult. It covers an area of about 80,000 square kilometres and is noted for its peculiar and difficult terrain. The whole area is transverse and crisscrossed by a large number of streams, swamps, canals and creeks. These peculiarities attracted the attention of even the colonial masters.

The Niger Delta has a long history of violence, which gets worse daily from year to year. Notwithstanding, the enormous economic contribution of the region to revenue generation and economic growth of the nation, the negative attitude of governments, activities of the oil companies towards the provision of infrastructure, service delivery, and economic development of the region, has have greatly formed the bases of violence and conflicts in the region. Despite the Niger Delta 
Ebekue: Nollywood Interventions in Niger Delta...

region, providing Nigeria's total proven reserves of oil standing close to 25 billion barrels, which is an estimated 1.8 percent of the proven global reserves (Chiluwa,199); the indigenous people are one of the most impoverished people in the world (Ahonsi, 30).

Following the discovery of crude oil and exploration in Nigeria in 1956, the contribution of the Niger-Delta region to national economy changed from a primarily fishing and agrarian to production of barrels of crude oil. The region became the major source of revenue to the Nigerian government. An attendant consequence of this is the total neglect of economic and infrastructural development, industrial waste, noise, pollution, overpopulation, exploitation, poverty, deprivation. The destruction of the natural environment and the livelihood of the local inhabitants as a result of frequent oil spills, ecological disasters have accelerated the deterioration of the socioeconomic and health conditions of peoples.

Consequently, this triggered crisis resulting in conflicts in the Niger Delta region. Some communities of the region began to stage protests against the activities of the oil companies which degraded their environment and endangered their lives with negligence to clean up the oil spill and payment of compensation to the people. The peaceful protests and rallies were often interrupted by the police, and that in some cases turned out to be very violent. Environmental Rights Action (296) observed that, in 1987, when the Iko once again held a peaceful demonstration against Shell, the notorious Mobile Police Force (MPF), locally known as "kill-and-go" was called. A total number of 40 houses were destroyed and 350 people were made homeless by the MPF's attack.

In 1990, Ken Saro-Wiwa dedicated himself to the amelioration of the Niger Delta Oil conflicts. Focusing on his homeland, Ogoni, he launched a non-violent movement for social and ecological justice, "Movement for Survival of the Ogoni People (MOSOP)". With this platform, Ken SaroWiwa challenged the oil companies and the Nigerian government and accused them of waging an ecological war against the Ogoni. Later same year, he moved the campaign to an international level seeking help for the plight of Ogoni people. Hence, in August 1991, exactly a year after first being signed, the Ogoni Bill of Rights was amended to authorize MOSOP to make an appeal to the international community for assistance after they had received no reply from the Nigerian military government (Boele, 42). 
To this end, Saro-Wiwa submitted the Ogoni Bill of Rights and his book titled "Genocide in Nigeria: The Ogoni Tragedy" to the United Nation Working Group as part of his evidence on the deteriorating state of the Niger Delta.

By October 1992, Saro-Wiwa went to London and warned that; “it's just going to get worse, unless the international community intervenes" (Rowell, 304). Later in December 3rd, MOSOP presented its demands to those oil companies operating in Ogoni land, including Shell, the Nigerian National Petroleum Corporation (NNPC) and Chevron (Boele, 42). They requested that the companies pay royalties and compensation within 30 days or quit Ogoni land. Consequently, in 1993 the oil companies pulled out of Ogoni, but this never brought peace and solution to the oil conflicts; rather the conflicts kept escalating. Sequel to this, Saro-Wiwa and 20 other Ogoni members of MOSOP were jailed. Ken Saro-Wiwa was later executed in 1995.

After the Biafran war of secession in the 1960s, the six states that constitute the Niger Delta have been sites of intense violence. Until amnesty programme of President Yar'Adua's administration in 2009, the armed groups' activities continued which includes blowing up of oil pipeline, kidnapping of oil workers and politicians, gun battle between militant groups and security forces.

\subsection{Films as an Artistic Intervention in the Context of Conflict Management}

Film as an artistic intervention especially in the context of conflict management has its effectiveness hinged on its communication potential. Film is a medium of communication and as well an art. Nigerian film industry therefore can through the use of film contribute to the development of African culture. "We are often reminded that film is a powerful medium of entertainment and the transmission of cultural values" (Orewere cited in Onuzulike, 45). Film and theatre as art forms which have not only the potential to champion human development but can impact on conflict management. Critics have posited severally the essence and potency of drama and film in all facets of human development which include conflict management. Hence, African conflict resolution model is anchored on the dramatization of the issues involved in conflicts. It is on this backdrop that film has championed conflict intervention and management. In the context of conflict management, Olaoba et al opine "the 
Ebekue: Nollywood Interventions in Niger Delta...

performance level of conflict resolution in African societies enabled participants in the ensuing drama to further understand and depreciate that custom and norms bequeathed to them by their ancestors" (58). He further asserts that, historically, the performance as you will get to know had always been stage-managed by notable dramatic personae, etc. However, film also involves characterization and role play by cast who play out different roles to depict a fiction or non-fiction situation or an event. Dramaturgical device always involve a systematic radiation of all sides (scenes) to the conflict (drama).

The idea of conflict, its management and resolution have led to such terms as peacemaking, peace-building, conflict prevention, peace enforcement, mediation, etc. It is germane to state that proper management of conflict usually ends in the creation peace, but when reconciliation fails, conflict escalates to chaos, crisis or war. In the light of above, the relevance of film which is an aspect of performing arts cannot be over emphasized.

Art have been heralded as a panacea for all kinds of problems of which film is not exempted. Costello as cited in Joshua Guetzkow is of the opinion that "arts revitalize neighborhoods and promote economic prosperity" (2). Espousing this, Williams also cited in Joshua Guetzkow (2) opines: "film as an art provides a catalyst for the creation of social capital and the attainment of important community goals".

Film has a great potential for creating a common basis and hence cultivate conditions for conflict transformation through characterization and depiction of conflict situations. However, it can serve it can inform and educate by securing a free flow of accurate and constructive information, counteracting misperceptions, identifying the interests underlying the issues, and helping to build a consensus (Sandra Melone et al, 3).

Film as an artistic intervention in context of conflict management may act as watchdog on leaders to help ensure long-term accountability, monitor human rights violations and, in a broader sense, provide some early warning on potential escalations of oil related conflicts. Taking cognizance that the essence of conflict management is the transformation of psyche both within the society and the individual, societies have to be involved from the top-down and the bottom-up. Therefore, Melone (15) observed that, the media have the potential to 
be a gateway through which to reach the largest possible number of people.

\subsection{Theoretical Framework Structural-Functional Theory}

Structural Functional Theory is deployed by the researcher to explain the relationship between the society, the people and conflict. The duo of Nancy Kingsbury and John Scanzoni propounded the theory in 1993 to ascertain the relationship between social structures, its constituent elements and social functions. Structural Functionalism is a broad perspective in anthropology and sociology and is predicated on the argument that society is a structure with interrelated parts. Functionalism addresses the society as a "whole" in terms of function of its constituent elements such as norms, customs, traditions, institutions, etc. However, social structures are stressed and placed at the centre of social functions deduced from the structures.

The argument of the theory is predicated on the claims that functionalism is the oldest and dominant conceptual perspective in society. Hence, the key arguments are that; firstly, a system is a framework which investigates any group that work together to produce some results (whole part and systemic interrelationship). A system is composed of regularly interacting and interrelating group of activities. It is a dynamic equilibrium model. There are often properties of the whole which cannot be found in the properties of the elements. Therefore, this theory becomes quite pertinent in this work because the work is predicated on how the activities of the different blocs in the Niger Delta conflict either escalates or douses the conflict which affects the whole of the Niger Delta community.

The researcher adopted the case study approach of the qualitative research method for his data acquisition and analysis of the film which constitutes the primary data for the research. Textual analytical method was used for the interrogation of the secondary data obtained from government archives, public and private libraries and the national news sources. The film Black November was randomly chosen among other movies with the similar thematic thrusts.

\subsection{Synopsis of Black November}

Black November, as directed and produced by JetaAmata, is a representation of the volatile oil-rich delta region of Nigeria where the 
Ebekue: Nollywood Interventions in Niger Delta...

people's fishing livelihood is marred by oil-spillage that engulfs the rivers, killing aquatic lives. The film depicts pictures marked by filthiness and degradation from neglect or poverty which aggravates the sensibilities of the militant youth of the community. A multinational company pays compensations and a section of elders misappropriate. Consequently, a group mobilizes to wage war against these corrupt elders, government and multi-national oil corporation, ostensibly to protect their land from being destroyed by the activities of oil exploration, drilling and spillage. Upon the arrest, detention, prosecution and death sentence passed on Ebiere, the supposed leader of the group for masterminding the brutal execution of some chiefs, a rebel fraternity storm America to seek justice by kidnapping an American oil executive to press their demand for the release of Ebiere. While also, a part of an American city is held hostage by the rebel group with rifles and explosive devices, riotous agitations are carried out in different parts of the Niger-delta area, especially at the premises of the oil workers. These agitations, however, leave gruesome destructions of lives and property to the detriment of the indigenes. Through flashback technique, the movie unfolds the commonplace narrative of the Niger-delta people, who are a practical example of the paradox of being so rich with oil and yet among the most wretched people in the world.

\subsection{Analysis of Black November in the Context Niger Delta Oil Crisis}

Black November (2012) is an artistic exposé of the crisis that has bedeviled the Niger Delta region of Nigeria since the discovery of oil in the area. The filmmaker, JetaAmata, through this film, contributes to the numerous attempts at restoring peace in the area and bringing to fore the evolution of the crisis from a popular perspective. Though, the film is a fictional tale of the Niger Delta experience, its thematic preoccupation is a representation of real life events and experiences. Thus through this film, the viewer is schooled to understand the following cardinal points about the crisis:

i. How it all began

ii. The role of the government in the escalation of the crisis

iii. The international dimension to the crisis 
iv. The popular Niger Delta attitude to the crisis

v. The possible ways forward

In other to critically and clearly achieve an analysis of this movie in the light of the lingering crisis in the Niger Delta, the researcher will sectionalize the discussion in subtopics.

1. The root causes of the Niger Delta crisis

2. Government Attitude to the Niger Delta Problem

3. International Dimension to the Crisis

4. Solutions to the Problem

These themes formed headings under which the analysis was made.

\section{$i$ The Root Causes of the Niger Delta crisis from the Prism of Black November}

Niger Delta oil conflict has become an age long conflict that has resulted tremendously in a massive loss of lives and properties. The narrative of this crisis has its marker pegged on the discovery of oil in Oloibiri shortly before independence. The Niger Delta region before this all-consuming discovery survived on their aquatic resources which began to extinct with the discovery of oil. Since then, there has begun a constant struggle for the control and distribution of the oil resources generated from the region. Beloveth Nwankwo attributes the crisis to "revenue allocation formula and resource control, federalism, environmental degradation, state imposed poverty, unfulfilled promises made by the government to mention a few". Jeta makes this fact glaring by painting a close picture of what the Niger Delta experience is. He sets the film in a typical Niger Delta squalor to show case the pity daily lifestyle style of a people from whose land the resources that has built ultra-modern cities like Abuja and Lagos are generated. In Scene 6 of the movie, a montage shows a kid defecating from a canoe. The excrete falls into the water and close to this scene a woman scoops water from the same river and drinks. This scene must have been painstakingly plotted by Jeta to showcase the low living condition of a typical Niger Delta community. The effect 
Ebekue: Nollywood Interventions in Niger Delta...

of such living will be evident in the constant spread of diseases and flu in such places. The following outburst from Tamunor and his colleagues summarize it all:

Tamunor: my people are dying

$2^{\text {nd }}$ Militant: our lands are devastated

$\mathbf{3}^{\text {rd }}$ Militant: our farm lands, livestock, wild life all gone

In effect, the people are pitched between dying in silence and dying to survive. The people's sources of livelihood are daily impaired by the activities of the oil companies. Their agrarian nature is continually oppressed by the daily spills that render the lands unproductive. This is same with their aquatic life which faces a similar fate from the spills. Government indifference contributes in fueling the crisis as the people feel betrayed and abandoned. Sunny Ikhioya is of the opinion that:

...the root cause of the whole Niger Delta crisis is injustice. The conspiracies of the old colonial masters, in tandem with the different international oil companies, IOCs, Shell, Mobil, Chevron, Total, Agip, etc and the activities of our dictatorial and uncaring federal government caused this situation we found ourselves, in not heeding to appeals for the basic rights of the minority oil producing nations, they have caused the manifestations of violent rebellions from the people. (Par. 1)

The underlying message from the film shows that the crisis is a creation of greed, indifference and the lack of attention to popular cries. Thus the warning from Ebiere to the representatives of the Western Oil and the colluding elders: "if you do not change your ways, the people will rise". It was the failure of both the government and the Western Oil to listen to the cries of the host community that makes Dede and his group resort to arms.

\section{ii. Government Attitude to the Niger Delta Problem}

A popular African adage has it that an elder does not sit at home while the goat delivers in tether. The elder in African parlance plays a very important role because of the high regards that Africans have for age 
and constituted authority. The government is always like an elder whose role is to see to the wellbeing of its citizens by providing it with basic amenities and protection of lives and properties. It is pertinent that one questions the activities of the government while these crises brewed. However, from the movie it is obvious that the government has not done enough to ameliorate the crisis. The federal government makes more than $70 \%$ percent of its revenues from the oil in the region. However, the people are aggrieved that the government does not care about their welfare as no amenities are put in place to carter for the many who are displaced by the activities of drilling in the area. The multinationals know this as evidenced in the reply given to Tamunor by the Director of Western Oil "you cannot blame me for your government". Faced by the dilemma of towing a populist ideology or following the directives of the government, the director goes on to lament "We have a corrupt military government breathing down our goddamn necks". It is obvious that the government is the villain in the movie as its policies and activities were anti-people. First, it neglects its duties of enforcing cleanup of spills and would not give a swift action to complaints on the spill but will quickly dispatch the police to accuse the people of stealing from the government when they begin to scoop from the spills. This is evident in the following altercations between the police and Mama Ebiere at the scene of the spill.

Police: You are all under arrest

Mama Ebiere: What is our crime?

Police: Stealing, this fuel is the property of the federal government of Nigeria

Mama Ebiere: So what would you rather we do, Standby and watch the property of the federal government spill?

Police: It is your duty to report any leakages in the pipeline

Mama Ebiere: But we did last week and no one came here to do anything about it

Police: I warn you not to continue 
Ebekue: Nollywood Interventions in Niger Delta...

Mama Ebiere: What would you do, shoot me? Which is worse, watch fuel flow past your house and yet in three days you cannot get one gallon of what your federal government cannot make available?

The scenario results in an ugly explosion as the reckless police man lights a cigarette and the whole place is set ablaze. The government instead of managing the situation properly by looking into the agitation being made by the people in order to provide a lasting solution begins to engage them with force. The natives are killed severally and their women raped while the men are beaten. The government betrays the trust of the people when they dubiously invite Dede and his militant group to a peaceful dialogue in order to proffer a solution to the lingering conflict. Dede and his friends are brutally murdered by the military team sent to contract the dialogue. This toughens the community and makes the youth to take a strong resolve not to give up the struggle but to advance it to a new level. At the burial of Dede and his group who were murdered by government forces after they were wilily lured to a peaceful dialogue, Ebiere gives the following oration:

They have killed our brothers, our mothers, our sisters, our fathers and even our children but what they cannot kill is our spirit. For every time they put a knife through us we only get stronger.

'They' in the oration is used in place of the government. The people feel betrayed that a government who like a father should bring them closer and solve their afflictions is killing them and making them look like common criminals. This lack of honor on the part of the government would result more ruthless kidnappings and killings. Thus the director through this narrative infers that honesty is paramount in managing conflicts. He also infers that a more humane approach in tackling the crisis will give better results than brute force.

iii. International Dimension to the Crisis

The Niger Delta oil is drilled by multinational companies who represent international interests in the Nigeria Oil and gas sector. However, the film uses the name 'Western Oil' to represent these 
companies as virtually all of them are from the west. Jeta through the instrumentality of his film Black November accuses these oil companies of failing in their duties to take care of their host communities and ensure their welfare. After the explosion that happened as a result of leakage in the pipeline, the representative of the oil companies together with the corrupt elders, who claim to represent the people, come to offer compensation for the lives that were lost in the explosion. Ebiere who only returned from the UK confronts them:

You come here enriching yourselves from the spoils of our land in the process wiping out families and generations, yet you keep the fuel burning. Give the people a rest and they will rely on you.

It is very obvious that the multinationals do not want a long term solution to the problem, they cut corners to provide short term relief to the people. As a result, they inundate the elders with bribe in order to keep the people in check. They believe that every Nigerian can be compromised with bribe. One could see the shock on the MD's face as he asks "Which Nigerian does not accept bribes?"Jeta indirectly implied in the movie that the oil companies are responsible for the woes Nigerians face in getting oil related products. Their monopoly and double dealings have made it impossible for any refinery to function in Nigeria. As such crude products are very exorbitant and make life ostensibly difficult as virtually everything depends on it. Tamunor cries out:

We export crude oil to you people only to import refine oil, why? Because western oil and our corrupt government won't allow our refineries to work

It is also disheartening to know that the international communities, who the oil from the Niger Delta service their local economies, think that the indigenes who are agitating for fair treatment are rascals, militants and terrorists. Instead of intervening and calling on the Nigerian government to stop the hanging of Ebiere, the American President blurts it out by stating that the "United states government does not negotiate with terrorists". In a bid to salvage the situation, rather than heed the people's plea to intervene, they deceive the agitators from Nigeria into thinking that Ebiere has been released and 
Ebekue: Nollywood Interventions in Niger Delta...

shortly after that she is hung in Nigeria. By setting the film in Nigeria and the United States, Jeta points out the obvious fact that the Oil crisis in the Niger Delta of Nigeria is hydra-headed. Thus, all the parties involved directly or indirectly must bear the interest of the people at heart for the conflict to be easily resolved.

\section{iv. Solutions Proffered in Black November}

Jeta in the film does not mince words in saying that any long term solution to the crisis must be popular-centric. For him, since the struggle started as a result of denial of a people's rights to basic amenities and sources of livelihood, any solution that will have a long term focus must be people centered. Through Ebiere, who is the hero figure in the movie, he drops it point blank:

It is high time you started to think more of the people other than your selfish fat pockets as well as that of your goons and cohorts. If you do not change your ways, the people will rise

Thus, from this it is very evident that the only way to getting a lasting peace in the region is by effecting a people oriented policies. Thus, not too long after the film, there have been continued calls for resource control and passing of the petroleum industrial bill which is hoped will bring peace and calm to the troubled delta.

\subsection{Conclusion}

The direct impact of oil exploration in the Niger Delta has been felt by everyone living in the area. Some of these issues include ecological degradation, environmental pollution, and lack of economic growth, associated human rights abuses, high inflation and loss of livelihood, poor governance and poor attitudinal response to the concern of the people of the region by both the government and oil multinationals. We have seen the different ways as portrayed in the film: people are victimised by poor condition of life, unemployment, and exploitation of various forms. The study has been able to highlight some of the root causes of the Niger Delta crisis. Analytical inference from the film discussed shows that the government handling of the Niger Delta Oil crisis has been poor and appears to lack sincerity. Added to this, is the nefarious roles played by the international oil firms who dubiously play politics their corporate social responsibilities to the 
host communities. In view of this, the researcher makes the following recommendations:

I. The federal government as a matter of urgency must institute a peace panel that will serve as a mediator between the people and the government. The committee must be sincere enough to look into the root causes of the Niger Delta problem, engage the people through peaceful dialogues and recommend the right compensation initiatives to the government.

II. The government should as a matter of urgency make moves to ensure that the Petroleum Industrial Bill (PIB) is passed in the parliament and instituted in order to effect resource control. By so doing, the people will become directly in charge of their God given resources, tap it and know how best to use it to affect their communities.

III. The clean-up of Ogoni land project that was instituted by the government of President Goodluck Jonathan should be hastened and followed with a fast degree of seriousness. This will show the strong resolve by the government to clean the communities. It will buy the government a certain degree of integrity. This move will make dialogue with the communities a lot easier.

* Emmanuel Onyekachukwu Ebekue, Department of Theatre and Film Studies, Nnamdi Azikiwe University, Awka - Anambra State, Nigeria, oscarmenia007@gmail.com

*Michael Chidubem Nwoye, Institute of Peace and Strategic Studies, University of Ibadan, Ibadan dubemicky@gmail.com 
Ebekue: Nollywood Interventions in Niger Delta...

\section{Works Cited}

Action, Environmental Rights. Shell in Iko - The Story of Double Standards. London: Routledge, 1995.

B.C, Onwubiko K. History of West Africa. Ibadan: Longman Publishers Limited, 1973.

Black November. Dir. Jeta Amata. Perf. Mbong Amata, Enyinna Nwigwe and Hakeem Kae-Kazim. 2012.

Boele, R. "Ogoni - Report of the Unrepresented NatMission to Investigate the Situation of the Ogoni of Nigeria ." 1995.

Chiluwa, A. "Media Representation of Nigeria's Joint Military Task Force in the Niger Delta Crisis." International Journal of Humanities and Social Science 1 (9) (2011): 197-207.

Chioma, Onyeneje Justina. "University of Nigeria, Nsukka. Institution Repository." 03 July 2016. University of Nigeria, Nsukka. Institution Repository. $13 \quad 10 \quad 2017$ <http://hdl.handle.net/123456789/2238>.

Comission, Niger Delta Development. "Niger Delta Regional Development Master Plan." 2006.

Ebewo, Patrick. "The Emerging Video Film Industry in Nigeria: Challenges and Prospects." Journal of Film and Video (2007): 46 - 57.

Ejibunu, H. T. "Nigeria's Niger Delta Crisis: Root Cause of Peacefulness." European University of Peace Studies (2007): 10.

Guetzkow, Joshua. How the Arts Impact Communities: An introduction to the literature on arts impact studies. https://www.princeton.edu/ artspol/workpap/WP20\%20\%20Guetzkow.pdf, 2002. 
Hogan, Michael and M McGinley. Niger River; Encyclopaedia of Earth. Washington DC: National Council for Science and Environment, 2013.

Hopkinson, P. Role of film in Development. Paris: Place de Fontenoy, 1971.

Ikhioya, Sunny. "Real issues in the Niger Delta crisis." 31 May 2016. Vanguard News (online). 24 October 2017 $<$ https://www.vanguardngr.com/2016/05/real-issues-in-theniger-delta-crisis/>.

Jim, Oviasuyi P. O. and Uwadiae. "The Dilemma of Niger Delta Region as Oil Producing States of Nigeria." Journal of Peace, Conflict and Development Issue (2010): 115.

Melon, Sandara, Georgios Terzis and Ozsel Beleli. "Usinfg the Media for Conflict transformation: The Common Ground Experience." Management, Berghof Research Center for Constructive Conflict. Berghof Hand Book for Conflict Transformation. Berlin: http://www.berghoffoundation.org/fileadmin/redaktion/Publications/Handbook/ Articles/melone_hb.pdf, 2002.

Michael, Hogan and M. McGinley. Niger River; Encyclopaedia of Earth. Washington DC: National Council for Science and Environment, 2013.

Niger, Delta Development Comission. "Niger Delta Regional Development Master Plan." 2006.

"Nigerian film corporation." n.d. 24 October 2017 <http://www.bpeng.org/sites/bpe/upcoming\%20transactions/ Media/Nigerian\%20Film\%20Corporation.pdf >.

O, Oviasuyi P. and Jim Uwadiae. "The Dilemma of Niger Delta Region as Oil Producing States of Nigeria." Journal of Peace, Conflict and Development (2010): 115. 
Ebekue: Nollywood Interventions in Niger Delta...

Onuzulike, U. "Nollywood: The Emergence of the Nigerian Videofilm Industry and its Representation of Nigerian Culture."

https://books.google.com.ng/books?isbn=0549258442 2007.

Onwubiko, K. B. C. History of West Africa. Ibadan: Longman Publishers Limited, 1973.

Onyeneje, Justina C. "University of Nigeria, Nsukka. Institution Repositiory." 03 July 2016. University of Nigeria, Nsukka. Institution Repositiory. $13 \quad$ October 2017 <http://hdl.handle.net/123456789/2238>.

Petters, S. W. "Conversation and Development of the Niger Delta." Petters, S. W. A People United, A Future Assured. Abuja: Nigerian Federal Ministry of Information, 2000. 197.

Report, The Willink Commission. The Willink commission Report. 1 July $1958 . \quad 18 \quad 10 \quad 2017 \quad<$ http://eie.ng/wpcontent/uploads/2014/03/TheWillinkCommissionReport_co nc_recom_lt.pdf $>$.

Rowell, A. Green Backlash - Global Subversion of the Environment Movement. United Kingdom: Routledge, 1996. 